Wilfrid Laurier University

Scholars Commons @ Laurier

6-2002

\title{
The Plight of Paternalism in French Child Welfare and Protective Policies and Practices
}

\author{
Alain Grevot \\ Wilfrid Laurier University
}

Follow this and additional works at: https://scholars.wlu.ca/pcfp

Part of the Family, Life Course, and Society Commons, and the Social Work Commons

\section{Recommended Citation}

Grevot, A. (June 2002). The plight of paternalism in French child welfare and protection policies and practices. Paper presented at the Positive Systems of Child Welfare Conference, Waterloo, ON.

This Positive Systems of Child and Family Welfare International Conference (2002) is brought to you for free and open access by the Reports and Papers at Scholars Commons @ Laurier. It has been accepted for inclusion in Partnerships for Children and Families Project by an authorized administrator of Scholars Commons @ Laurier. For more information, please contact scholarscommons@wlu.ca. 


\section{Partnerships for Children and Families Project}

The Plight of Paternalism in French Child Welfare and Protective Policies and Practices

A. Grevot 


\title{
The Plight of Paternalism in French Child Welfare and Protective Policies and Practices
}

\author{
Alain Grevot
}

\begin{abstract}
For 40 years, the French child protection system has been based on a structure set up at the dawn of the Fifth Republic, giving a strong role, and a monopoly to the State to support families in trouble. The role of Children's Judges has been designed to personify the constitutional duty of the State to control and support the role of parents as defined by the civil code. The evolution of the structure of French society (family models, multicultural communities), the impact of more liberal economic and social policies (in a country strongly characterized by centralization and Jacobinism), the growth of the role of local authorities in welfare policies, the impact of the European convention on human rights about judicial proceedings, and the appearance of lobbying by 'poor families' organizations' has led to major policy and service delivery changes in 2002.
\end{abstract}


The Plight of Paternalism in French Child Welfare and Protective Policies and Practices Alain Grevot

\section{Evolution of the French Child Welfare and Protective System Between the Seventeenth}

\section{Century and 2002}

\section{8-1945: The Prehistoric Years ${ }^{1}$}

In 1638, the first Charity Organization for Lost Children was founded by Saint Vincent de Paul in Paris, followed more than a century later by the Lost Children's Hospital in 1761. Until the revolution of 1789 , charity action focused on the consequences of poverty, and mostly on abandoned children. The well-known tower system was the only official form of State intervention (the tower was a State-sanctioned building where mothers could leave their children in a small enclosed room where they were cared for by nurses and the mother's confidentiality was preserved).

The French revolution brought a completely new concept: the primacy of paternal power. Paternal power was the legal right, based on the roman civil code, possessed by a father, giving him a limitless power over his children. For revolutionary legal experts, the aim was less to develop a child protection strategy than to break the family model of the aristocracy, a symbol of despotism. Nevertheless, this reform defines a key paradigm still at work in 2002: the child as supported by the State, not simply because of the child's susceptibility, but because of a sentiment that the child is also a rightful future citizen of the State.

In 1810, the first penalty for serious abuse of a child emerged in the Napoleonic criminal code, notwithstanding the fact that by this time the Napoleonic civil code (1807) had restored the central power of the father in the French family. In 1814, the State began to play a (limited) role in the supervision of children living in foster care. In 1832, the first mention of sexual abuse appeared in the criminal code with the indecent behaviour offence. 
By the end of the nineteenth century, children slowly became the subject of legal rights, with laws on children at work and compulsory schooling — one of the most symbolic First Republic's policies. In 1889, a new breach in paternal power was made with the introduction of provisions in the civil code that left a father open to the possibility of forfeiting his parental rights. In 1892, the very first law on child abuse and neglect was formed and, at that time, Dr. Tardieu published in Paris his forensic study on a child physical abuse syndrome.

The beginning of the twentieth century saw the formation of several key initiatives in legislation for the protection of children. The first child welfare administration (Service d'aide à l'enfance) was established in 1904, as the responsibilities of Church and State were officially separated. In 1912, the function of Children's Judge — a professional and specialized judge in charge of juvenile delinquency cases - was created. He worked with a probation service, employing the ancestors of Éducateurs spécialisés (child social worker)—one of the two main corps of social workers, the other one being Assistantes sociales (generic social workers), modeled after the role of social nurses. With the 1933 law on neglected and abandoned children, the first stage in constructing the French system came to a close.

\section{The Welfare Years and the Birth of the Existing French System}

In 1945, as was the case in many western European countries, the role of the State greatly expanded, leading to the creation of a welfare state, including social insurance and family allowances. The 1946 French Constitution declared France to be an indivisible, secular, democratic and social republic.

One of the first legislative decisions of the 1945 national union government was the pivotal law about juvenile delinquency. Firmly centered on the priority for- educative (education and treatment) answers to juvenile delinquency (until age 21), this law established the Children's Judges as the moral 
authority of the child welfare system, far ahead of the social services that were still in their infancy. Since the public child welfare social services were still focusing primarily on abandoned children, for nearly 15 years it was common for 'pioneer judges' to give flexible interpretations of the law to allow social workers to deal with a much broader range of troubled children. This group of very committed Children's Judges pushed hard for the development of local non-profit organizations to help children and families in trouble; very often the Judges were personally involved in the creation of these Associations for the Protection of Childhood and Adolescence (Association de sauvegarde de l'enfance et de l'adolescence).

In 1958, Charles de Gaulle returned to power, and with him a large group of influential Social Democrat or Christian Democrat civil servants. In the wake of a new constitution (the Fifth Republic), they developed a wide range of public policies aimed at generating a stronger French economy that would be more attuned to social development through the role of State and public services.

It was a time of rapid urbanization, immigration, and demographic growth. The first months of this new political and economical era saw social work begin to be established as an integral part of national development. The contemporary child and family welfare and protection system is rooted in the spirit of the Fifth Republic, with a symbolic alliance between the State and the family for the upbringing and education of children—child being understood both as a member of a family as well as a citizen to be.

In 1958, the Children's Judges obtained what they had been lobbying for since 1945: a new law regarding children in danger - the law about Assistance éducative became the foundation of judicial protection. As a result, Children's Judges were responsible not only for responding to instances of juvenile delinquency, but also for more general cases of children in trouble. Because of this shift in 
responsibility, Children's Judges found themselves involved with parents as often as their children. The law on Assistance éducative made Children's Judges the secular arm of the State with a responsibility to support parents in their role. Children's Judges had the power to limit parental rights, but not to suppress them, or to definitively separate children from parents. Since the core concern of the law was the existence of a danger for the child, it left the gates open for two actions: the first, a rather informal and open dialogue between the judge, the parents, and the children; and the second, the implementation, by a new kind of social and educative service (called AEMO: Action éducative en milieu ouvert-AEMO), of judicial orders offering help and counseling to the family with the stipulation that Judges be able to monitor the development of the child's living conditions with parents and relatives.

A year later, in 1959, the next step was made with the publication of the act regarding administrative protection— the precursor to the modern French child protection system. The code included a duty for social services, at that time a State administration, to develop a large repertoire of social work strategies to bring help, support, and counseling to families facing social difficulties likely to endanger their well-being. These forms of intervention included voluntary or negotiated care for children. For judicial protection, the key concept was 'danger,' while for the administrative field it was 'risk of danger.' No one ever found a clear and precise terminology to define the concept of danger, but work went along on this basis for nearly thirty years. The structure of the system designed in 1958/59 could be represented under two separate levels, each divided into two fields completely funded by the State.

The first level, mixed proactive global social action, aimed to lead the way for the health and social development of the country (primary prevention), and the administrative protection of children, based on voluntary or negotiated interventions (secondary prevention). This level was under the 
responsibility of the National Health and Social Affairs administration (DASS), a State administration with a national management and 99 local administrations (DDASS)—one for each département, an administrative and geographical jurisdiction created by the French revolution. Each local DDASS included three departments: (1) the Social Services Department; (2) the Mother and Infant Health Protection Department (PMI); and, (3) the Child Welfare Department (Aide social à l'enfance), responsible for administrative protection. Each DDASS was organized in a local health and social team called Circonscription d'action sanitaires et socials serving an average of 25,000 inhabitants. These local teams were composed of members of each of the three DDASS departments: a group of general social workers (Assistante sociale de secteur), one for every 5,000 inhabitants; along with nurses, midwives, pediatricians, home aid workers, family economy social workers, child social workers (Éducateurs spécialisés) and one psychologist. The Mother and Infant Health Protection Department (PMI) worked closely with the École maternelle - a free public pre-school for 3 to 6 year-old children that is available everywhere in France-and developed mobile health centers in rural areas. The Aide social à l'enfance (ASE) departments of DDASS worked not only with their own teams, based in the local units, but also with the network of children's homes and foster care services from the non- profit sector. The French non-profit sector was born in the post-war period as the State developed its social policies using its own public services and non-profit organizations (by means of agreements generating financial and technical control over the non-profit organizations).

The second level of the 1958/59 system included the judicial protection field, led by the Children's Judges and their close partners, the large social and educative service of the Action éducative en milieu ouvert (AEMO). These officials implemented supervision and educative orders over children living with their parents or relatives. Care orders were implemented by the local 
DDASS-Aide sociale à l'enfance departments with their own children's home (emergency units) or foster care services and the network of children's homes and foster care services from the non-profit sector.

Between 1975 and 1979, the national social affairs policy focused on a concept of global social action, and on the strong link of global social policies with prevention and protection social policies. A 1979 report from the Social Affairs Inspectorate (Bianco-Lamy, IGAS, 1980) promoted a very preventative and global approach difficulties. Its guiding principles were widely implemented. The DDASS local units encouraged collaboration among all their members, and the 1975-1985 period was characterized by the large development of the human and technical resources of both public and non-profit sector services. The impact of this policy between 1973 and 1983 can be assessed by the decrease of the number of children in the care of the child protection system on a judicially enforced or voluntary basis. The number of these children fell from 235,000 in 1973 to 140,000 in 1983 $50 \%$ of whom where under State care on a voluntary or negotiated basis (http://www.sante.gouv.fr/drees). It was the apogee of the welfare-oriented period in France.

Soon after came the commencement of a new period during which the State ordered its administrations and non-profit partners to prioritize the economic and social development of France, with a particular focus on populations not conforming to these expectations. Major changes in France were causing pressure on the generous and rather paternalistic family and children welfare system. The impact of 1974 economic crisis (e.g., runaway unemployment rate), the rise of consciousness about the existence of a large multi-ethnic (mostly north-African) adolescent population in urban areas, the impact of the evolution of women's rights (equal parental rights between father and mother, 1971; contraception, 1971; legalization of abortion, 1975), and the transformation of the 'traditional' family model, all contributed an to the strain on the welfare system. 
The non-profit organization ATD-Fourth World (ATD: Help for All in Distress), a voluntary

organization working with poor families, focused at that time on the promotion of a minimum income allowance (created in 1988). During this time, their militant criticism of social work, especially child protection strategies, gave both service providers and politicians a poorer public image.

\section{Two Sources of Change: The Sudden Awareness of Intra-family Maltreatment and the Decentralization of Child Protection Responsibilities}

In addition to the above pressures, the destabilization of the child welfare and protection system, between 1983 and 1989, came from two other sources: the decentralization of child protection from State level to the level of local authorities, and the newly initiated concepts of physical and sexual abuse.

The 1981 socialist government decentralized many State powers to local authorities. This was a significant change in a country that had been deeply rooted in a culture of centralized powers. The State put social work and child welfare and protection responsibilities in the hands of Conseils généraux —a level of local authorities nearly unknown to the majority of French people and whose role was, for two centuries, a very minor one. The government intended to bring decision-making over social affairs closer to the people directly affected by the decisions, and also wanted to harmonize the French system with other European countries. One factor that severely inhibited progress was that the State had clearly lost control over child protection expenses $(+10 \%$ per year) at a time of economic crisis (1974-1984). Furthermore, no national data gave any idea of which children were being named 'at risk' or 'in danger,' and why they were so named, and for what purposes.

All the DDASS administration personnel (social services, PMI and Aide sociale à l'enfance) were transferred from State control to Conseils généraux, but a substantial number of technical 
decision-makers from DDASS chose to stay with the State, rather than go to the local authority. This created a serious loss for the child protection system, because very often the new technical decisionmakers were unskilled in social work and child protection.

More generally, the decision to decentralize child protection responsibility was made in spite of the reservations and criticisms levied by social workers. For most academics and social work practitioners, the intrusion in the private family sphere was legitimated by the original Republic's alliance between the State and family. For them, the move to take the main responsibility for child protection from the State level to the weakest level of the French democracy (Conseils généraux) was illegitimate. As a result, Justice suddenly became, for a majority of child protection practitioners, the only source of credibility for involvement in cases dealing with children in serious trouble. This change would have important consequences five years later because of a new factor destabilizing the system: an increased awareness of the issue of child maltreatment.

At the Montréal International Society for the Prevention of Child Abuse and Neglect Conference, a small group of pediatricians and Ministry of Social Affairs civil servants—all founding members of the French Association for the Information and Research on Child Abuse (AFIREM) came in contact with, and reacted positively to, North American ideas about child abuse and neglect. They were especially impressed by initiatives from Québec. In France, they lobbied for action by the Government and the Ministry of Social Affairs launched its very first campaigns against the physical (1985) and sexual (1987) abuse of children.

These two campaigns, based on television and newspaper advertisements, had a very strong impact. These messages were reinforced by new non-profit organizations created by survivors of abuse as well as by media stars. These new groups developed very aggressive strategies towards the official child protection system and effectively exposed the general public to the dark side of family 
life. Everywhere in the French- speaking world (especially in countries in the Caribbean and Indian ocean), children and adults began to talk about serious abuse of children and social work practitioners changed their perspectives on these issues. On July $10^{\text {th }}, 1989$, the Prevention of Abuse of Children legislation was enacted. The Act gave local authorities the duty to set up a permanent plan of action to collect information about abused children and to investigate all suspected cases in cooperation with the justice sector. Compulsory reporting of abuse was required for everyone involved in the primary and secondary prevention service sectors. At the same time, the education system became involved in this national fight against child abuse. After years of silence and secrecy (that often served to protect abusive teachers), a very clear order was given to all teachers and school staff: refer to the judicial prosecutor all forms of abuse you suspect may be taking place.

The new law also required that local authorities train all service providers in the subject of maltreatment, and to collect data about the incidence and prevalence of abuse. To share in this mission, the local authorities set up, jointly with the Ministries of Social Affaires and Justice, a national registry of children in danger $(O D A S)$. Having found that it was nearly impossible to collaborate without a common language, ODAS (http://www.odas.net) made it a priority to elaborate a comprehensive glossary, since words such as danger, referral, and maltreatment had no agreed upon common meaning within the field.

Under the basic ODAS definitions, maltreated or abused children are children who are victims of physical violence, mental cruelty, sexual abuse, or neglect producing grave consequences for their physical and emotional development. Children at risk are children who are subject to living conditions that can put in danger their health, safety, morality, education, or upbringing, but who are not otherwise maltreated. Children in danger encompass the whole of the two preceding categories. 
These definitions were used for the annual data collection that was implemented in 1994. For the first time, some kind of overview about who entered the French child protection system was anticipated. However, these new definitions did bring with them some confusion. The 1958/59 system was based on the idea that children at risk of danger were under the charge of administrative protection and children in danger were under the charge of the judicial system. In 1991/92, as the use of the $O D A S$ glossary spread across all child protection services, nearly all children at risk of danger became labeled in danger, as a result of the change in definitions. Some Children's Judges critiqued this change, but the social pressure for a quick and effective answer to child abuse negated any voice of opposition.

The July 1989 Act had a deep impact, not only on the new local authority social services, but also on service providers working with children perceived as being in trouble. The ensuing ten-year period was a time for emphasizing child protection more than child and family welfare.

\section{The Recognition of the Reality of Abuse and Neglect and the Power of the Public Response}

The 1994-1997 period saw a dramatic increase in reported maltreatment cases (especially sexual abuse, which moved from 5,500 recorded cases in 1995 to 6,800 in 1997), but the following years are characterized by the stabilization of this sort of case (Table 1 shows the number of children referred to Aide sociale à l'enfance (ASE) between 1994 and 2000).

Table 1: Children Referred to Aide sociale à l'enfance Between 1994 and 2000

\begin{tabular}{|l|c|c|c|c|c|c|c|}
\hline & 1994 & 1995 & 1996 & 1997 & 1998 & 1999 & 2000 \\
\hline $\begin{array}{l}\text { maltreated } \\
\text { children } \\
\text { children at } \\
\text { risk }\end{array}$ & 17,000 & 20,000 & 21,000 & 21,000 & 19,000 & 18,500 & 18,300 \\
\hline Total & 58,000 & 65,000 & 74,000 & 82,000 & 83,000 & 83,500 & 83,800 \\
\hline
\end{tabular}


The emphasis on more protective approaches in the French child protection field had some positive impacts: the French community was made to face the reality of the dark side of family life and, as a result, were forced to make significant alterations to the state of institutional life (in schools, children's homes, etc.). In the report to the Parliament published in September 2000 (GIPEM, 2000), the Ministers of Social Affairs and Justice gave evidence describing cases of child physical, emotional and sexual abuse that were being served. In 1996, police forces followed social services in setting up annual data collection procedures for these cases. The results showed that child sexual abuse investigations and prosecutions were growing - from 14,211 in 1997 to 16,434 in 1998 . Criminal Justice recorded a similar trend -575 sexual crimes (rapes by parents/adults having responsibility for the child) in 1994, 715 in 1997 and 602 in 2000; 2,579 sexual assaults on minors were reported in 1994, 4,233 in 1997, and 4,666 in 2000.

The severity of sentencing increased dramatically during the first five years of the nineties. An incest case (with rape) is now sentenced by 5 to 20 years of imprisonment. In 1997, the government supported a national campaign on child abuse and neglect. On July 7, 1998, a new Act on perpetrators and victims of sexual abuse dramatically improved the support offered to child victims of sexual abuse in criminal proceedings. Instructional video recordings, the development of the child advocate (Administrateur ad hoc), therapeutic support and other services were now offered to victims of abuse. In 1999, the Ministry of Social Affairs published a guidance report on the prevention and treatment of institutional violence. During the same period, sentences against teachers and sports trainers, as well as judges, priests and bishops, were making national news headlines.

Between 1997 and 2000, the annual national conference on child abuse and neglect addressed, in succession, the issues of physical abuse, emotional abuse, sexual abuse and the benefits and costs of long term care for maltreated children. In 1998, 272,050 children and adolescents (less than $0.2 \%$ 
out of 15 million people aged under 19) were the subject of some form of child protection interventions (see Table 2).

Table 2. Child Protection Interventions in 1998

\begin{tabular}{|c|c|}
\hline Actions & Number \\
\hline $\begin{array}{l}\text { home aid } \\
\text { financial aid }\end{array}$ & $\begin{array}{l}\text { 25,000 families } \\
450,000 \text { families }\end{array}$ \\
\hline $\begin{array}{c}\text { Family supervision } \\
\text { orders (Action } \\
\text { Educative en Milieu } \\
\text { Ouvert) }\end{array}$ & 128,850 children \\
\hline $\begin{array}{l}\text { Administrative Care } \\
\text { based on negotiated } \\
\text { basis, implemented by } \\
\text { local authorities. }\end{array}$ & $\begin{array}{ll} & 31,000 \text { children } \\
? \quad & \text { Foster care: } 62,000 \\
? & \text { Residential care: } \\
41,000 \\
? \quad \text { Other forms of } \\
\text { care: } 12,500\end{array}$ \\
\hline $\begin{array}{c}\text { Judicial care orders } \\
\text { implemented by local } \\
\text { authorities }\end{array}$ & 84,500 children \\
\hline $\begin{array}{l}\text { Judicial care orders } \\
\text { implemented by family } \\
\text { or other individuals }\end{array}$ & 27,700 children \\
\hline
\end{tabular}

\section{The Destabilization of Child Protection System: Red Lights on the Dashboard}

The rapid implementation of compulsory child abuse referrals to the Local Authorities' social and health workers who were in charge of the most preventative actions, even supported by the large investments in the development of a program of continuous training, had negative effects on these personnel. They lost confidence in their ability and in their right to work with families in trouble if they had fear about the safety of children, or any doubt about parental capacities to face and solve the problems of their children. The result was the growth of referrals to Justice (see Table 3). Also of significance is the change in the ratio of children who were put in care based on judicial orders: 1 out of 2 in 1980, 3 out of 4 in 1998. 
Due to the changes in referrals, the 352 Children's Judges had to respond at any point in time to 145,000 cases of children deemed to be in danger. This increase meant an average number of 440 files by Judges for their civil activity—at a time when dramatic growth of juvenile delinquency was already exposing them to greater public pressure.

A study published in January 2001 (Deschamps, 2001) provides some telling statistics:

? $100 \%$ of parents or children had no access to their files before the hearings;

? $98 \%$ of reports sent by fax or given by social workers the day of the hearings were used for the proceedings;

? In $87 \%$ of hearings, social workers and family members are heard at the same time during the hearing;

? In $61 \%$ of hearings, Children's Judges give full information about the file's content (referral report, investigation report, review report);

? The average time for serious case hearings was 41 minutes; and

? Only 5.2\% of Children's Judges' orders were subject to appeal.

Most of the investigative services (Action éducative en milieu ouvert) had long list of cases waiting for many months to be served. For example, the JCLT investigative service had its workforce increased three times between 1998 and 2002, but a number of cases equal to one third of its operational capacity were still waiting to be served in January 2002 (Deschamps, 2001). 
Table 3. Children Newly Referred to Aide sociale à l'enfance (ASE) and the Ratio of Cases Passed on to Justice (ODAS, 2000)

\begin{tabular}{|c|c|c|c|c|c|c|c|}
\hline & $\mathbf{1 9 9 4}$ & $\mathbf{1 9 9 5}$ & $\mathbf{1 9 9 6}$ & $\mathbf{1 9 9 7}$ & $\mathbf{1 9 9 8}$ & $\mathbf{1 9 9 9}$ & $\mathbf{2 0 0 0}$ \\
\hline $\begin{array}{c}\text { referrals to } \\
\text { Justice by } \\
\text { Aide } \\
\text { sociale à } \\
\text { l'enfance }\end{array}$ & 31000 & 36000 & 42000 & 49500 & 49000 & 47500 & 47500 \\
\hline $\begin{array}{c}\text { cases } \\
\text { treated by } \\
\text { local } \\
\text { authorities } \\
\text { (Aide } \\
\text { sociale a } \\
\text { l'enfance })\end{array}$ & 27000 & 29000 & 32000 & 32500 & 34000 & 36000 & 36300 \\
\hline $\begin{array}{c}\text { total of new } \\
\text { children in } \\
\text { danger } \\
\text { cases }\end{array}$ & 58000 & 65000 & 74000 & 82000 & 83000 & 83500 & 83800 \\
\hline $\begin{array}{c}\text { proportion } \\
\text { of total new } \\
\text { children in } \\
\text { danger } \\
\begin{array}{c}\text { cases } \\
\text { referrals to } \\
\text { Justice }\end{array}\end{array}$ & $53 \%$ & $55 \%$ & $57 \%$ & $60 \%$ & $59 \%$ & $57 \%$ & $57 \%$ \\
\hline
\end{tabular}




\section{Strengths and Weaknesses of the System in 2001: The Challenge of Preserving the Positive Nature of the System}

As already discussed, the French child protection system involved roughly 300,000 children and adolescents in 1998. This section will first look at some financial ambiguities of the current system. Second, we will examine why and how the system has been placed under scrutiny in recent years. Finally, we will present a thematic summary of results of five official studies of the French child protection system published between 1999 and 2001.

\section{More Money, Fewer Children, but What About Prevention Interventions?}

As the Social Affairs Inspectorate concluded, some figures of the French child protection system are really hard to define (Naves-Cathala, 2000). A striking example of the system's financial ambiguity is its cost. The overall French social protection expenses were, in 1999, 389 billion Euros. Local Authorities social service expenses (which covers the elderly, people with disabilities, and children and families—-some 830,000 people in all) were 12 billion Euros. Child welfare and protection's part of the social service expenses were 4.6 billion Euros, and the Family Allowances System's special social action funds were 2.3 billion Euros (global Family Allowances expenses are 38 billions Euros).

The financial analysis of the consequences of the decentralization of child protection from the State to local authorities shows two main characteristics: (1) more money spent on fewer children; and, (2) more money spent on placement, less on other forms of intervention. Child protection expenses grew $85 \%$ through the $1984-1999$ period as the number of children involved in child protection interventions fell from 333,000 to 269,000 . Residential care cost an average of 120 Euros per day in residential care and 80 Euros in foster care. Child care (placement) costs consume $75 \%$ of the budget, as the balance of expenditure patterns shifted towards placement and away from 
prevention and treatment interventions. The Action éducative en milieu ouvert interventions, the largest unit working with children in danger and their families, saw social workers with caseloads of 15 to 25 families at the same time, even if their teams included psychologists and psychiatrists. State expenses for Juvenile Justice (courts and investigative services) are unknown, as are health expenses related to child protection.

\section{A Child Protection System Under Scrutiny: Why and How?}

By the end of the twentieth century, three new elements influenced the evolution of the balance between welfare and protection, and disturbed the relations between families and child protection professionals. One came from the users of these services, another from the jurisprudence of the European Human Rights Court, and a third from the development of professionals' awareness about the importance of evaluating service and management practices.

The non-profit organization $A T D$-Fourth world - the voluntary organization working with poor families which lobbied the 1988 socialist government to promote a minimal income allowancestrengthened its links and influences with the Minister of Social Affairs directly and through the media. $A T D$-Fourth world called for an enquiry focusing on the impact of poverty and precarious living conditions on child care decisions in child protection interventions. The Minister of Social Affairs and the Minister of Justice, two majors members of the socialist government, asked the Inspectorates of Social Affairs and Justice to investigate why and how voluntary and judicial care orders in the child protection field were decided. The investigation included interviews with professionals, parents, children, decision-makers in Aide sociale à l'enfance administration as well as Children's Judges, and also analyses of the content of referrals and judicial files. The NavesCathala report was published mid-2000 and was actively relayed by media who, for the first time in France, began making bitter critiques against service providers. In the wake of this report, the 
Minister of Family and Children set up a commission of service providers, decision-makers and academics and asked them to answer questions about the evolution of relations between parents and professionals. Their final report (Roméo, 2001) was widely commented on by the media and it was officially presented by the Minister at the Etats généraux de la protection de l'enfance in November 2001 (Etats généraux is a very symbolic word in French as it was the name of the first revolutionary national assembly in 1789).

The sentiment that the French Assistance éducative judicial proceeding was something too constrained and specific had grown within the corporate body of judges, and especially amongst Children's Judges. To keep safe the humanist spirit of the 1958 founders, it was considered important to review the content of these proceedings to prevent criticism from the European Human Rights Court for unfair trials, the key concern being the lack of direct access by families to the judicial files and the place and role of barristers. The Garde des sceaux (Minister of Justice) asked a group of judges and practitioners to suggest changes to these procedures. The methodology included a questionnaire that was sent to every Children's Judge in France.

At the same time, the $O D A S$ national observatory of children in danger published its pilot study on the ways children and parents move through the child protection system. For five years, the work of ODAS had highly influenced the evolution of Aide sociale à l'enfance professional culture. Based on the work of small groups of Aide sociale à l'enfance officers, it helped to increase the awareness of French decision-makers about the importance of observation and evaluation. The influence of JCLT's European comparative studies was extremely significant at this level. ODAS studies impelled the politically powerful Local Authorities Assembly to produce a study (DPJJ/ADF, 2001), jointly with the Ministry of Justice, of the functioning of the child protection system in 16 local authorities. In 
addition, the year 2000 saw the publication of the first annual report from the newly named Child Ombudsman. A large part of this report's content focuses on child protection interventions.

\section{Thematic Summary of Five Official Reports}

\section{(Children and Families)}

First and foremost, the five reports share the assessment that family models are now more widely diverse, complex, and fragile. They also conclude that protection services' users are now calling professionals to account for their methods. The second major area of agreement is that professional workforces demonstrate questionable ways of thinking about two main groups of users of their services.

Families living in sensitive urban areas make up the first group. France faces a big crisis in her inclusion model, which had worked quite well for the last two centuries for people coming from all over Europe or from Christian cultures overseas. Members of the large north-African population that had immigrated to France in the 1960's, and the west-African permanent population that are part of the current flow of immigration to France, are the major victims of recent economic and social changes. The French universalistic republican model is based on individual inclusion with people progressively interiorizing French values and social models, even if they keep links with their original cultures. Immigrant north-African families, for many years, had a difficult decision to make in determining whether they would stay in France or move back to Algeria, Morocco or Tunisia. Children born during the 1970's and 1980's were guided by ambivalent parents. Most of these children were brought up by adults who were facing both a breakdown of cultural perspectives and economic plight as industrial changes made them susceptible to unemployment.

The role of fathers' and women's status became, during the 1980's, the subject of ideological dispute s between French social workers and north-African families. Later on, things became more 
and more complex as the classic north-African family model faded and social work and juvenile justice failed to develop more appropriate approaches to understanding the new French northAfrican family ways of living. If many young people from north-African communities became involved in community-based activities (sports, culture, day-care), a very limited number of them continued on in the educational system to become qualified social workers. This fact is mirrored by the limited representation of people coming from other cultures and races in French political and administrative staff. Day by day, the weight of mutual negative representations became heavier between a number of immigrant families, as well as families living with limited resources, and social workers, leading more families to avoid contact with public social services.

National social programs were designed to reduce the social costs of urban social housing areas built in the 1970's. These housing areas were seen as having very negative impacts on child development, especially in educational attainment, but also resulting in the deep stigmatization of the people living there. A social and cultural divide had developed, concealed by the public image of France as shown, for example, by the multi-ethnic 1998 soccer world championship team. These issues continue to be underestimated in local and national political discourse, because they challenge the universal and inclusive image of our nation.

Adolescents make up the second group drawing attention. The Child Ombudsman's Annual Report (2001) stated that, in 2000/2001, our country saw adolescents as a major threat. The trend started during the 1980's with the dramatic increase in aggressive behaviors of young male groups in sensitive urban areas, but, as schools were increasingly open to revealing — because of the impact of governmental child abuse policies—violence at school was becoming commonplace. The daily media publicity covering serious incidents (barbarous murders or assaults of young people by peers, group rapes, etc.) involving adolescents from all social classes and cultures found audiences across all the 
political spectrum. Public perceptions put enormous pressure on child welfare, and other social workers and therapists, including Children's Judges. As a result, some of the official reports described a serious panic among professionals during the 2001 investigations.

The third major agreement about families in the recent official reports is that economic and social precariousness increase the pressure on parental skills and new family education responsibilities. The reports also point out that child protection professionals focused on intra-family relationships more than on contextual parameters such daily living conditions.

\section{Professional Practices}

These five official reports agree that it is a matter of urgency to reduce the gap between the worlds of service users and service professionals. The preferred method to reduce resistance is to link supports for the parental role and child protection interventions. These reports promote the

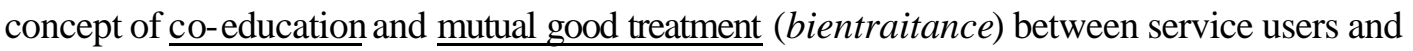
professionals, even if these practices may potentially generate a deep upheaval in professional practices and the nature of qualifications of social work teams. Governmental recommendations suggest the development of methods to assess family resources and strengths (moving beyond an exclusive focus on family weaknesses and malfunctioning), and extending to include the nature of the wider family and social environments.

For the first time in France, official documents recommend that a limit be placed on the involvement of Children's Judges in child protection work. The ideas in these reports about the child protection system focus on agreements, contracts, and partnerships among service users and social workers. This is seen as the basis for the end of the monopoly of the current ongoing concept of beneficiary, meaning that the users call for service and the concerned administration decides whether or not to offer this service in ways defined only by itself. The studies conducted by the 
JCLT Research Department clearly showed that French professional practices used negotiations less often than other continental European child protection systems, Belgium or Germany for example.

Nearly all of these reports identify a need for more formal and informal support for front-line service providers. These reports state that most generic social workers such as Assistante sociale de secteur, or community based health professionals such as PMI nurses and pediatricians, are facing paradoxical expectations, since the introduction of compulsory abuse reporting in 1989 merged with their welfare orientation to work. The challenge of introducing more protection expectations in a welfare- oriented system had weighed heavily on front-line service providers. Facing more complex and fragile family cases, local authorities' service providers globally were generally seen as receiving poor support from their management. The main recommendation in these reports was having much clearer reference to social work principles and procedures, most specifically in child welfare and child protection work, after more than 40 years of legal emphasis.

\section{Institutional Missions}

The 2002 French child protection system was the result of the accumulation of many legal texts from 1958 to 2000, and areas of serious confusion among these texts have been identified by these official reports. The most serious confusion was seen as the numerous overlapping focuses in the Children's Judges' (Justice) and local authorities' (administrative) respective legal responsibilities. Belgium and Germany faced the same problem before 1990/91, but decided to move to a more distinctive role of these two sectors. Priority has been given in these two countries, by means of a new law, to voluntary child welfare work by official social services, with Justice playing a subsidiary role.

However, similar statements to those expressed in Belgium and Germany led, in France, to efforts to clarify jurisdictions by non-compulsory local negotiations. It proved nearly impossible in 
2001/2002 to introduce explicit and binding changes in the structure of the system as each party to the negotiations feared to interfere with the jurisdictions of other parties.

Nevertheless, local authorities, social services, and Children's Judges continue to try to improve the clarity and understanding of the system for its users. This objective is supported by the January 2002 Social Work Act. This legislation requires that all public and non-profit welfare and protection institutions prepare documents describing their internal rules and procedures, develop service plans for individuals, collect and take into account service users' points of view, and offer service users access to their files.

This 2002 Social Work Act introduces a new concept for French service providers: the duty of all institutions to design self-assessment methods for their own performance and to call for external evaluation of their actions every five years. A National Council of Evaluation has been created including members of different administrations, academics and service providers, and service users groups. Its mandate is to approve assessment methods and personnel, and also to promote good service practices.

\section{Legal Aspects}

If new laws intend to enhance the rights of service users in 2001/2002, they are not the first effort to implement this ambition. The 1984 law on the relations between local authorities' child protection social services and their users was, as were many other official rules, not correctly implemented by staff and social workers. So, the government intends to restart the development of official inspections by the General Inspectorate of Social Affairs, a State department.

For the first time in France, in the spring of 2002, national television channels and newspapers strongly castigated child protection professionals for the way they treated families and children in child protection proceedings and interventions. For this author, it resembled England, where this kind 
of event has regularly existed for many years. Even if this attack was sometimes based on stereotypical cases, it produced positive pressure on professionals and it helped those working to change the way of thinking about service users. For example, the Deschamps report (2001), based on their analysis of child protection judicial proceedings, gave birth some months later to a new act in March 2002, giving parents and children direct access to their judicial files in Children's Judges' courts.

\section{Conclusion: The Plight of Paternalism and the New Balance Between Welfare and Protection}

The first years of the twenty-first century could be an important benchmark for the French child welfare system. Initially designed during the 1950's—at a moment of rapid economic and demographic development—as a welfare- oriented system, the French system interiorizes the global spirit of a republican French State-citizen relationship, which was, for many centuries, characterized by a responsibility of the State to define and safeguard the common interest. The State appointed a large network of professionals on the whole French territory, with important strategic links between all resources, like the École maternelle and PMI department, for example, and a preoccupation with coherence and consistency. The Children's Judges were the key actors of this system, mixing a paternalistic role and an active promotion of parental responsibilities.

The hard confrontation with the reality of the extent of serious abuse and neglect cases, started at the end of the 1980's, promoted the influence of criminal proceedings on child protection work and, during the 1990's, strongly reduced spaces for dialogue and negotiations among service professionals and service users. But it also showed that French practices were in many ways dramatically discretionary and confusing. In the global context of the social evolution of French society (family models, multicultural communities), and with the impact of more liberal economic and 
social policies, counter influences came to light (especially through legal proceedings and in the media). The whole system (service providers, policy-makers, judges) started to question its practices and values.

The content of many different official documents (national surveys, inspection reports, and laws) published between 2000 and 2002 shows that the systemis clearly changing. These texts demand more legibility in interventions and decision-making, call for a new balance of powers between service users and professionals, and support the promotion of assessment, both of family potential and the quality and impact of potential interventions.

The core idea behind these changes is modifying the relationships among professionals and service users through the promotion of the concept of co-education (a French Republican version of the enabling and empowering Anglo-Saxon concepts). The new priority given to social workers and to all professionals in child welfare is to be clear about what they propose to do to be closer to families' daily living realities, and to help families to discover and to use their own resources to reduce, as far as possible, the dangers for their children.

The first decade of the twenty-first century will be characterized by the retirement of nearly $60 \%$ of the child welfare and protection workforce. Young professionals are entering the system at a key moment. In a global French context of social and moral crisis, they start to work facing 'multiproblem' families with clearer institutional references and are much more aware of issues like emotional, physical or sexual abuse than their elder colleagues were at the same step of their own careers. Even if some criticisms of these new procedures are surfacing, the public message sent to professionals still focuses more on the need to help families in trouble than to blame them, as a large consensus exists about the legitimacy of the concept of co-education, which means a State-parent shared responsibility for child rearing. 
The concept of co-education can be the heart of a new dynamic for the French system, a large proportion of professionals are deeply committed to it; however, the inertia of a strong paternalistic culture and the reality of a poor methodological preparation can put a curb on this evolution. The short term development of the French democracy will weigh heavily on the child protection system, as no social work practices can be too far from the core values held by the nation. Is it possible to promote negotiation, balance of powers, and open-mindedness in a country now lost in its fears of change, responsibilities, and opening to other cultures? The next years will provide us the answer. French child welfare and protection practitioners have to play a role in that evolution; they can now build on legislation that supports clearer values and ways of working. 


\section{Appendix 1: Glossary}

Administrative protection: Interventions based on voluntary or negotiated intervention and implemented (directly or by non-profit organizations ordered and funded by local authorities) by the administration of the Local authority (Département). This administration is composed of three different departments:

1- Aide Sociale à l'enfance (ASE): Child Welfare department which works not only with their own teams (social workers, psychologists) based in local units, but also with the network of children's homes and foster care services from the non-profit sector by means of conventions and agreements producing a very close financial and technical control on it.

2- PMI department: the Mother and infant Health protection department that implements primary and secondary free social and medical actions for children under the age of 6 . Their professionals (nurses, nursery nurses, pediatricians) are firmly linked with hospitals and "Ecole maternelle" - a French free/public pre-school for 3-6 years-old children.

3- Service Social: generic social work implemented by assistante sociale de secteur.

Professionals of these three departments are based in the same local unit named Circonscription d'action sanitaires et socials - an average of 25,000 inhabitants per unit.

Children's Judges Juges des enfants (JE): professional and specialized judges trained in a threeyear program in the Ecole Nationale de la Magistrature in Bordeaux and Paris. The JE's jurisdiction includes:

? Juvenile delinquency . He/She jud ges both in office hearings and court hearings. He/she leads investigation (except crimes), and follows up the implementation of decisions.

? Children in danger. He/She judges in office hearings, leads various kinds of investigations, and follows up the evolution of the case by means of planned or emergency hearings.

? Since 1974 (change of the minority age from 21 to 18) young adults (18/21) in trouble.

? Control of the use of family allowances.

? In the "assistance educative" field (Children in danger), he/she has to know about children's cases if the health, safety, or morality of the child is threatened or if educative conditions are seriously endangered. The threat has to be determined as being significant and the child has to live in France, whatever his/her nationality.

Cases come to the JE through several channels:

1 - Procureur de la République (Procurator) / He/She receives all kinds of referrals about children in danger (for example, in Département de Seine-Saint-Denis $52 \%$ of all referrals came from Local Authorities SSD, 7\% from Schools, 5\% from Hospitals and private doctors; $11 \%$ from Police and Gendarmerie, $19 \%$ from parents and children, $6 \%$ from relatives and neighbours). The Procureur can decide whether or not to refer cases to JE, to prosecute parents for confirmed incidents of abuse or neglect, to ask for police investigations, and to prosecute perpetrators of abuses.

2- Parents

3- Child her/himself (5\% of all referrals)

4- Judge her/himself, for example, when he/she has come to know of a child's situation through his/her knowledge of another case. 
? Children's Judges (JE) are only involved in the child's life on the basis of suspected danger. Divorce and parental conflicts, based on a child's up-bringing and education, belong to the Juge des affaires familiales' jurisdiction (JAF). The JE can have knowledge of a child 's case, in divorce or parental conflict situations, only if elements of danger influence the implementation of the JAF's decision, and generate the need of a modification.

? Children's Judges have to summon up educational, social, psychological, and material resources to restore failing or vacant parental authority. They can order:

1- Investigative orders named IOE (Investigation et orientation éducative) implemented by multi-disciplinary teams.

2- Family supervision and treatment orders, named Action éducative en milieu ouvert (AEMO) implemented by social work teams including also psychologists and psychiatrists.

? IOE and AEMO are mostly implemented by teams form the non-profit sector. IOE are funded by the Ministry of Justice and AEMO by the ASE department.

Care orders implemented by the ASE department which widely contracted with the nonprofit sector for that purpose. Care orders only restricted parental rights, Children's Judges do not have any power to definitively separate parents and children. These orders are reviewed every year.

Judicial protection: Group of interventions ordered by the Children's Judges to protect children in danger. 


\section{Appendix 2: Timeline of the Evolution of the French Child}

Protection System

\begin{tabular}{|c|c|c|}
\hline 1638 & $\begin{array}{c}\text { Foundation of the "lost children } \\
\text { hospital" in Paris }\end{array}$ & $\begin{array}{c}\text { First institution for abandoned } \\
\text { children }\end{array}$ \\
\hline 1789 & French revolution & $\begin{array}{l}\text { First breach in the Roman civil } \\
\text { paternal absolute power on } \\
\text { children. }\end{array}$ \\
\hline 1810 & Imperial Napoleon civil code & $\begin{array}{c}\text { restored paternal power but } \\
\text { introduced penalty for extreme } \\
\text { abuse on children }\end{array}$ \\
\hline 1889 & Republican civil code & $\begin{array}{l}\text { introduction of new items in the } \\
\text { civil code opening a father to } \\
\text { the forfeit of his parental rights }\end{array}$ \\
\hline 1892 & Dr. Tardieu's forensic works & $\begin{array}{l}\text { study on child physical abuse } \\
\text { syndrome }\end{array}$ \\
\hline 1912 & $\begin{array}{l}\text { Creation of Children's Judge } \\
\text { function }\end{array}$ & $\begin{array}{c}\text { A professional and specialized } \\
\text { judge in charge of juvenile } \\
\text { delinquency cases }\end{array}$ \\
\hline 1933 & legal evolution & $\begin{array}{c}\text { law on neglected and } \\
\text { abandoned children }\end{array}$ \\
\hline 1945 & $\begin{array}{c}\text { legal evolution: Ordonnance de } \\
1945 \text { sur les mineurs } \\
\text { delinquents }\end{array}$ & $\begin{array}{l}\text { law about juvenile delinquency. } \\
\text { Firmly centered on the priority } \\
\text { for 'éducative' answers to } \\
\text { juvenile delinquency (until age } \\
\text { 21), this law established the } \\
\text { Children's Judge as the moral } \\
\text { authority of the child welfare } \\
\text { system }\end{array}$ \\
\hline 1958 & $\begin{array}{c}\text { legal evolution (ordonnance): } \\
\text { the concept of judicial } \\
\text { protection: Assistance } \\
\text { educative }\end{array}$ & $\begin{array}{c}\text { the Children's Judge got power } \\
\text { to protect children in danger } \\
\text { and kept their role for young } \\
\text { delinquency. }\end{array}$ \\
\hline 1959 & $\begin{array}{l}\text { legal evolution (ordonnance): } \\
\text { The concept of administrative } \\
\text { protection: Protection } \\
\text { administrative, implemented } \\
\text { by Aide Social à l'Enfance, a } \\
\text { department of the DDASS, a } \\
\text { State local administration. }\end{array}$ & $\begin{array}{l}\text { The Family and Social Action } \\
\text { code included a duty for State } \\
\text { social services, to bring help, } \\
\text { support, counseling to families } \\
\text { 'facing social difficulties } \\
\text { endangering their well-being.' } \\
\text { These interventions included } \\
\text { voluntary or negotiated care for } \\
\text { children, and are based on the } \\
\text { concept of risk of danger. }\end{array}$ \\
\hline
\end{tabular}




\begin{tabular}{|c|c|c|}
\hline $1984 / 85$ & $\begin{array}{c}\text { Decentralization of } \\
\text { administrative protection } A S E \\
\text { from State to local authorities } \\
\text { (Départements) }\end{array}$ & $\begin{array}{l}\text { All the DDASS administration } \\
\text { workforces (social services, } \\
\text { PMI and ASE) were removed } \\
\text { from State to Départements, } \\
\text { equivalent to counties in many } \\
\text { English-speaking countries. }\end{array}$ \\
\hline 1989 & $\begin{array}{c}\text { legal evolution: July 1989, the } \\
\text { Prevention of Abuse on } \\
\text { Children Act. }\end{array}$ & $\begin{array}{l}\text { Gave to the local authorities } \\
\text { (ASE department) the duty to } \\
\text { set up a permanent plan of } \\
\text { action to collect information } \\
\text { about abused children and to } \\
\text { investigate all suspected cases } \\
\text { in connection with Justice, to } \\
\text { train all practitioners on the } \\
\text { subject of maltreatment, and } \\
\text { to collect data about the } \\
\text { incidence and prevalence of } \\
\text { abuse. }\end{array}$ \\
\hline 1991 & $\begin{array}{l}\text { Creation of the national } \\
\text { observatory of children in } \\
\text { danger. }\end{array}$ & $\begin{array}{c}\text { The priority action of ODAS } \\
\text { was to elaborate a glossary to } \\
\text { enable professionals to speak } \\
\text { about the same things. }\end{array}$ \\
\hline 1998 & $\begin{array}{c}\text { July } 17,1998 \text { Act on } \\
\text { perpetrators and victims of } \\
\text { sexual abuse }\end{array}$ & $\begin{array}{l}\text { improved the support offered } \\
\text { to child victims of sexual abuse } \\
\text { in criminal proceedings: vidéo } \\
\text { recordings, development of } \\
\text { child advocate (administrateur } \\
\text { ad hoc), therapeutic support. }\end{array}$ \\
\hline $2000 / 01$ & $\begin{array}{l}5 \text { official reports scrutinize the } \\
\text { French system at work. }\end{array}$ & $\begin{array}{c}\text { Recommend to reduce the } \\
\text { gap between professionals } \\
\text { and service users; } \\
? \quad \text { Promote negotiations } \\
\text { between professionals and } \\
\text { users before calling for } \\
\text { Children's Judges' } \\
\text { intervention; } \\
? \quad \text { Tend to clarify the } \\
\text { confusion between Children's } \\
\text { Judges (judicial protection) } \\
\text { and ASE (administrative } \\
\text { protection) jurisdictions. }\end{array}$ \\
\hline 2002 & March, 2002 law on the & ? Allows children and their \\
\hline
\end{tabular}




\begin{tabular}{|c|c|c|}
\hline & $\begin{array}{c}\text { evolution of judicial protection } \\
\text { Assistance educative } \\
\text { proceedings }\end{array}$ & $\begin{array}{c}\text { parents to read their judicial } \\
\text { files. } \\
? \quad \text { Aims to reduce traumas } \\
\text { produced by the impact of } \\
\text { discretionary decisions }\end{array}$ \\
\hline
\end{tabular}




\section{References}

Bianco, J. L., \& Lamy, P. (1980). “L'aide à l'enfance demain.” Paris. Ministère de la Santé et de la Sécurité Sociale.

Rapport GIPEM (2000). Ministère déléguée à la famille et à l'enfance. 'L'enfance maltraitée.” Rapport au Parlement Loi du 10 Juillet 1989. Groupe interministériel pour l'enfance maltraitée.

Deschamps, J-P. (2001). Rapports "Deschamps" au Garde des Sceaux sur "le contradictoire et la communication des dossiers en assistance educative." Rapport du groupe de travail présidé par Jean-Pierre Deschamps, Président du tribunal pour enfants de Marseille. Ministère de la Justice.

Naves, P., \& Cathala, B. (2000). Rapport "Naves-Cathala" d'inspection sur "l'accueil provisoire et placements d'enfants." IGAS http://www.sante.gouv.fr

Roméo, C. (2001). Rapport "Roméo" sur "l'évolution des relations parents-enfantsprofessionnels dans le cadre de la protection de l'enfance." Ministère délégué à la famille, à l'enfance et aux personnes handicapées. Ministère déléguée à la famille et à l'enfance.

DPJJ/ADF. (2001). "Evaluation et diagnostic des dispositifs de protection de l'enfance." Rapport final du comité national de suivi et d'évaluation Ministère de la Justice DPJJ \& Assemblée des Départements de France.

\footnotetext{
${ }^{1}$ For a glossary of terms in use in the French child welfare system, see Appendix 1. For a timeline of the evolution of the French child protection system, see Appendix 2.
} 


\section{SOCIAL WORK}

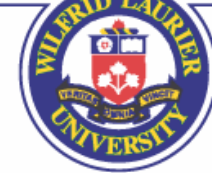

Partnerships for Children and Families Project

Wilfrid Laurier University

Waterloo, Ontario, Canada, N2L 3C5

Email: partnerships@wlu.ca

Local: (519) 884-0710 ext.3636

Toll Free: 1-866-239-1558

Fax: $\quad$ (519) 888-9732 